\title{
Kajian hukum tentang perdagangan berjangka di Indonesia
}

\author{
Henry Noch Lumenta ${ }^{\text {a, }}$ 1* $^{*}$ \\ ${ }^{a}$ Universitas Negeri Manado, Program Studi Ilmu Hukum, Manado, Indonesia \\ ${ }^{1}$ nochlumenta@gmail.com
}

\begin{tabular}{ll}
\hline \multicolumn{2}{l}{ Informasi artikel } \\
\hline Sejarah artikel: & \\
Diterima & $: 20$ Oktober 2019 \\
Revisi & $: 20$ November 2019 \\
Dipublikasikan & $: 6$ Desember 2019 \\
\hline
\end{tabular}

Kata kunci:

Bursa berjangka

Perdagangan berjangka

Hukum investasi

\begin{abstract}
ABSTRAK
Krisis ekonomi tahun 1998 yang melanda kawasan asia membawa pelajaran yang sangat penting bagi manajer perusahaan multinasional, maupun akademisi di perguruan tinggi. Pengambil kebijakan keuangan di negara-negara Asia tidak menyangka bahwa jatuhnya satu mata uang akan berdampak pada mata uang Negara lain. Di dalam situasi yang sulit itu perdagangan berjangka lahir menjadi penyelamat dalam nilai tukar mata uang secara implicit dalam dunia investasi.Tapi dalam perkembangannya transaksi di bursa berjangka banyak terdapat masalah maupun sengketa hukum yang sangat kompleks dalam hal perumusan regulasi baru menyangkut perdagangan berjangka sebagai akibat dari masalah yang ada dalam transaksi dalam bursa berjangka. Metode penelitian yang digunakan dalam penelitian ini adalah metode yuridis normatif, dimana peneliti menggunakan sumber bacaan serta sumbersumber hukum yang ada untuk menjawab permasalahan yang ada dalam penelitian ini. Kesimpulan dari penelitian ini ternyata perdagangan berjangka terdapat masalah hukum yang krusial menyangkut kewenangan pasar modal dan pasar berjangka karena pasar modal sendiri dapat ikut dalam transaksi yang sebenarnya merupakan kewenangan dari pasar berjangka, serta pada prakteknya banyak perusahaan pialang berjangka yang masih saja melakukan pelanggaran hukum kepada nasabah tapi tindakan tegas sangat sulit diambil disebabkan sulitnya pembuktian yang disebabkan karena mekanisme pasar yang begitu rumit dan flexibel.
\end{abstract}

\section{ABSTRACT}

\section{Keywords:}

Futures exchange

Investments law

Futures trading

\begin{abstract}
Legal studies on futures trading in Indonesia. The 1998 economic crisis that hit the Asian region brought very important lessons for managers of multinational companies, as well as academics in universities. Financial policy makers in Asian countries have no idea that the fall of one currency will have an impact on the currencies of other countries. In this difficult situation, futures trading is born to be a savior in the exchange of currencies implicitly in the world of investment. But in the development of transactions on the futures market there are many complex legal problems and disputes regarding the formulation of new regulations concerning futures trading as a result of problems existing in futures exchanges. The research method used in this study is a normative juridical method, in which the researcher uses the available reading sources and legal sources to address the problems in this study. The conclusion from this study turns out that futures trading has crucial legal issues regarding the authority of the capital market and the futures market because the capital market itself can participate in transactions that are actually the authority of the futures market, and in practice many futures brokerage firms are still violating the law for customers but decisive action is very difficult to take due to the difficulty of proof caused by market mechanisms that are so complex and so flexible.
\end{abstract}




\section{Pendahuluan}

Krisis ekonomi yang melanda kawasan asia membawa pelajaran yang sangat penting bagi manajer perusahaan multinasional, maupun akademisi di perguruan tinggi. Krisis itu sendiri dimulai dari jatuhnya mata uang Baht-Thailand yang disusul oleh jatuhnya mata uang PesoPhilipina, Ringgit-Malaysia, dan RupiahIndonesia. Pengambil kebijakan keuangan di Negara-negara Asia tidak menyangka bahwa jatuhnya satu mata uang akan berdampak pada mata uang Negara lain. Pada saat yang bersamaan ketidakhatihatian manajer keuangan perusahaan multinasional khususnya dalam pengelolaan dana asing telah mengakibatkan semakin terpuruknya mata uang Negara yang bersangkutan. Kondisi tersebut diperberat oleh kebijakan pendanaan yang tidak memperhatikan kesesuaian antara durasi pinjaman dan investasi yang dibiayai dengan pinjaman tersebut. Selain itu tidak dilakukannya hedging secara tepat untuk meminimumkan risiko perubahan nilai tukar atau foreign exchange risk. (Sartono, 2003)

Di dalam situasi yang sulit itu perdagangan berjangka lahir menjadi penyelamat dalam nilai tukar mata uang secara implicit dalam dunia investasi, serta semakin berkembang dan menjadi suatu investasi yang paling prospektif sampai sekarang ini sampai lahirnya Undangundang No 32 Tahun 1997 tentang Perdagangan Berjangka Komoditi, perdagangan berjangka adalah suatu komoditi yang sangat baru dan mungkin adalah sesuatu yang secara eksplisit belum diketahui secara luas oleh seluruh masyarakat Indonesia. Berbicara mengenai Perdagangan berjangka berarti pula kita membahas derivative (turunan) dari suatu kontrak, baik kontrak dari foreign exchange (valuta asing), Indeks saham, serta komoditi yang diperdagangkan, berarti kesimpulannya bahwa objek yang diperdagangkan dalam perdagangan berjangka adalah perdagangan kontrak atau margin dari suatu perjanjian jual beli yang menggunakan jangka waktu. (Lie Ricky Ferlianto, 2006)

Perdagangan berjangka sendiri merupakan suatu produk investasi yang masih sangat baru didalam kegiatan ekonomi di Indonesia, dan karena mekanismenya sangat rumit investor pun harus tahu tentang aturan, aspek hukum serta pengelolaan resiko dari dana yang akan ditanamkan oleh investor. Maupun untung ruginya berinvestasi dalam perdagangan berjangka.

Perdagangan di bursa berjangka atau futures trading, adalah dimana resiko yang coba dihindari oleh para pemilik modal dialihkan kepada para spekulan dalam pengelolaannya. Sehingga bisa dikatakan bahwa secara akademik perdagangan bercangkan setidaknya menimbulkan dua gugatan. Pertama, hal ini merupakan permainan zero sum game, jika dilihat secara sempit, dimana disetiap keuntungan ada pihak yang dirugikan. Kedua, presumsi bahwa penanam modal adalah individu penggemar resiko yang merupakan hal lumrah dalam bidang penanaman modal diabaikannya. Oleh sebab itu, mencari pembenaran atas teori yang ada masih lebih sulit daripada memperhatikan hal-hal yang sunggu terjadi dalam membela keberadaan bursa berjangka. Manfaat makro yang didapat dari bursa berjangka cukup banyak apabila dibuat dalam suatu daftar. (Mahmud, 2006).

Pasar modal sendiri diatur di dalam Undang-undang No. 8 Tahun 1995, sedangkan Undang-undang No. 32 Tahun 1997 mengatur tentang pasar berjangka. Kedua peraturan ini memiliki beberapa perbedaan, seperti dalam bursa efek masyarakat umum ditawarkan untuk melakukan jual beli surat berharga dalam bentuk efek yang telah terdaftar di bursa tersebut sebelumnya. Dengan demikian Pasar Modal merupakan tempat yang tepat dalam proses jual beli rights, warrants dan convertible bonds. Selain itu dalam pasar 71 dijelaskan bahwa penjualan pertama serta pembuatan suatu efek harus di luar bursa efek. Sehingga bursa efek hanya menjadi pasar sekunder, karena efek yang 
diperjualbelikan di bursa harus didaftarkan terlebih dahulu. Pengaturan tentang pasar primer dan pasar sekunder dari bursa efek yang boleh ditawarkan kepada masyarakat diatur dalam undang-undang pasar modal. (Anwar, 2010)

Perdagangan berjangka sendiri merupakan produk investasi yang sangat baru serta Pembentukan Hukum serta regulasinya pun sangat prematur jika kita lihat dari asal mula berdirinya, tidak dapat dipungkiri perdagangan berjangka mempunyai peranan yang sangat penting dalam pertumbuhan ekonomi, perdagangan serta keuangan di Indonesia. Regulasi dan aturannya pun harus jelas dan dilaksanakan dengan baik tentunya agar prosedur perdagangan di bursa berjangka dapat berjalan dengan baik. Tapi dalam perkembangannya transaksi di bursa berjangka banyak terdapat masalah maupun sengketa hukum yang sangat kompleks dalam hal perumusan regulasi baru menyangkut perdagangan berjangka sebagai akibat dari masalah yang ada dalam transaksi dalam bursa berjangka, dari hal ini penulis ingin mengkaji serta membahas Prosedur dan mekanisme transaksi perdagangan berjangka serta perlindungan hukumnya yang semuanya itu dirangkaikan dalam penulisan yang bertajuk "Kajian Hukum tentang Perdagangan Berjangka Di Indonesia".

Sengketa-sengketa

maupun permasalahan hukum dalam perdagangan berjangka begitu rumit dan kompleks sehingga perlu untuk penulis merumuskan pokok permasalahannya berdasarkan latar belakang yang telah dipaparkan, yaitu sebagai berikut: (a). Bagaimanakah pengaturan tentang investasi perdagangan berjangka di Indonesia? (b). Bagaimanakah Prosedur dan mekanisme transaksi serta perlindungan hukum terhadap investasi perdagangan berjangka di Indonesia?

\section{Metode}

Jenis penelitian yang digunakan dalam penelitian ini adalah penelitian hukum kepustakaan atau penelitian hukum normatif. (Sunggono, 2010) Penelitian hukum normatif adalah penelitian dimana norma serta aturan yang berlaku merupakan suatu konsep hukum. Hukum positif yang merupakan hasil dari suatu lembaga perundang-undangan dianggap sebagai norma hukum dalam penelitian ini (undang-undang dasar, kodifikasi, undangundang, peraturan pemerintah, peraturan presiden, dan sebagainya...)". (Muhammad, 2004)

Penelitian hukum ini bertujuan untuk mendapatkan suatu asas atau doktrin hukum yang berlaku. Tipe penelitian ini seting disebut sebagai "studi dogmatik" (Sunggono, 2010) Berdasarkan metode penelitian ini maka data dalam penulisan ini berupa data primer dan sekunder, seperti peraturan perundang-undangan mengenai pasar berjangka serta buku-buku atau literatur yang berkaitan dengan hal tersebut.

\section{Hasil dan Pembahasan}

\section{Pelaku Transaksi dalam Investasi Perdagangan Berjangka di Indonesia.}

Memperdagangkan komoditi dengan kontrak berjangka digunakan oleh mendapatkan lindung nilai merupakan kegiatan utama dari pelaku bursa yang terdiri dari produsen, pedagang ataupun perusahaan pemakai. Para investor dan spekulan berusahan mendapatkan keuntungan dalam bursa berjangka. (Lie Ricky Ferlianto, 2006)

Ada beberapa pelaku bursa yang terlibat dalam bursa berjangka, mereka dibagi ke dalam beberapa bagian seperti : Hedger : merupakan pengusaha atau pedagang yang melakukan bisnis di pasar tunai atau fisik atas komoditi yang kontrak berjangkanya diperjualbelikan di bursa berjangka. Hal tersebut dilakukannya untuk melindunginya dari perubahan harga komoditi yang beresiko membuatnya rugi. Kalangan eksportir biasanya merekalah yang merupakan buying hedger, atau yang memperdagangkan kontrak berjangka tersebut, selain mereka ada produsen dari komoditi tersebut, pemakai bahan baku 
pabrikan, dan sebagainya. Hal ini dilakukan untuk menjaga stabilitas dan keberlanjutan penyediaan pasokan. Pihak pabrikan seringkali menghadapi ketidakpastian harga bahan baku untuk menjaga keberlanjutan perusahaan, sehingga dengan adanya bursa berjangka komoditi ini bisa memberikan kepastian dalam perusahaan menjalankan pabriknya.

Selling Hedger (Hedger Penjual): Hedger penjual atau hedge short adalah penjual komoditi secara fisik di pasar pada masa depan. Kontrak berjangkan tersebut harus dijual dalam posisi short agar harga penjualan komoditinya bisa terlindungi. Produsen terutama petani merupakan pihak yang biasanya menjadi selling hedger. Hal ini bertujuan agar penurunan harga komoditi yang bisa saja terjadi tidak mempengaruhinya. Selanjutnya hedger harus melakukan penutupan kontrak yang dibeli. Apabila hedger mengambil posisi short di pasar berjangka, maka kontraknya harus ditutup dengan membeli di bursa berjangka. Apakah itu posisi long atau short, dalam melakukan offset jenis dan jumlah kontrak harus sama. (Lie Ricky Ferlianto, 2006)

Sepkulator adalah pedagang yang mencari keuntungan melalui perubahan harga suatu komoditi dengan antisipasi yang tepat. Hal ini dilakukan melalui transaksi sesuai dengan analisa ataupun perkiraan yang telah dibuat sebelumnya. (Lie Ricky Ferlianto, 2006)

Perdagangan berjangka sendiri dinaungi oleh beberapa lembaga yaitu lembaga pengawas, lembaga pelaku, dan lembaga penyelenggara. Kekuatiran oleh para investor dalam berinvestasi pada bursa berjangka komoditi diharapkan bisa dihilangkan dengan dibentuknya lembaga pengawas oleh pemerintah. Badan Pengawasi Perdagangan Berjangka Komoditi (BAPPEBTI) ditetapkan oleh pemerintah sebagai badan pengawas bursa berjangka sesuai dalam Undang-undang No. 32 Tahun 1997. Menteri Perdagangan merupakan pihak yang membawahi badan pengawas. BAPPEPTI sendiri diberikan kewenangan yang cukup banyak.
Kewenangan tersebut diberikan agar terjaminnya integritas pasar, integritas keuangan, dan nasabah/masyarakat terlindungi dalam sistem keuangan yang dibangun. Kewenangannya salah satu adalah memerintahkan pemeriksaan serta penyidikan dan memeriksa perizinan terhadap pihak yang diduga melakukan pelanggaran. (Lie Ricky Ferlianto, 2006)

BAPPEBTI dalam menjalankan tugas pokoknya memiliki kewenangan antara lain, menerbitkan izin usaha bagi para pihak yang terlibat dalam bursa berjangka, memastikan semua peraturan dan ketentuan yang telah ditetapkan dijalankan sebagaimana mestinya, selain itu BAPPEBTI juga berwenang utnuk menetapkan daftar bursa berjangka luar negeri yang bisa menjadi saluran dalam bursa berjangka dalam negeri, serta membentuk suatu alat dalam yang bertugas untuk menyelesaikan masalah yang berkaitan dengan kegiatan dalam bursa berjangka. (BAPPEBTI, 2014)

Bursa berjangka adalah organisasi yang berfungsi utnuk menyediakan fasilitas berguna untuk menyelenggarakan kegiatan perdagangan berjangka yang diawasi sesuai dengan peraturan perundang-undangan tentang future exchange yang berlaku. Bursa berjangka sendiri merupakan suatu badan hukum yang berbentuk perseroan terbatas yang terdiri dari sebelas badan usaha yang terkait satu sama lain. (Lie Ricky Ferlianto, 2006)

Bursa berjangka memiliki peran yagn berbeda dengan perseroan terbatas pada umumnya. Karena bursa berjangka adalah pengelola pasar berjangka yang berusaha memberikan kemudahan transaksi bagi para anggota. Setiap pemegang saham hanya diberikan satu saham, untuk menghindari kempemilikan mayoritas oleh suatu orang ataupun kelompok. Bursa sendiri dapat dihentikan, jika ditemukan bursa telah mengarah pada hal-hal yang berpotensi merugikan masyarakat. PT Bursa Berjangka Jakarta merupakan penyelenggaran kegiatan kontrak berjangka pertama di Indonesia. (Lie Ricky Ferlianto, 2006) 
Fungsi utama (Bursa Berjangka) Jakarta BBJ adalah menyediakan fasilitas bagi anggota untuk bertemu dan bertransaksi Kontrak Berjangka. Harga ditentukan melalui metode elektronis, melalui interaksi yang efisien berdasarkan permintaan dan penawaran dalam sistem perdagangan. Dua sistem perdagangan akan di implementasikan oleh BBJ yaitu, sistem satu harga per sesi dan sistem perdagangan kontinyu. BBJ melayani dua tujuan yang sangat penting yaitu penemuan harga dan pemindahan resiko. Informasi tunda harga dan pasar juga disebarkan melalui jaringan televisi dan radio lokal, media lokal dan internasional, dan juga melalui internet. (JFX, 2019)

Tugas divisi pengawasan dapat di klasifikasikan dalam tiga hal besar :
a. Audit dan Tata Tertib
b. Pengawasan Keuangan
c. Pengawasan Pasar

\section{Prosedur Serta Mekanisme Transaksi dan Perlindungan Hukum dalam Investasi Perdagangan Berjangka di Indonesia.}

Perlindungan Investasi.

-Perlindungan secara Hukum :

-Formulir Permohonan Pembukaan

Rekening (UU No. 32 Thn 1997 pasal 50)

-PPA (UU No. 32 Thn 1997 pasal 50 dan

SK Bappebti No. 9 Thn 2000)

-Laporan Transaksi (SK Bappebti No. 19

Thn 2000)

-Penyaluran Amanat ke Bursa Luar Negeri

(UU No. 32 Thn 1997 pasal 32 dan 33)

-Perlindungan secara Finansial :

-Rekening Terpisah (UU No. 32 Thn 1997

pasal 45 dan SK Bappebti No. 17 Thn

2000)

-Modal Bersih Disesuaikan (SK Bappebti

No. 10 Thn 2000)

-Dana Kompensasi (UU No. 32 Thn 1997

pasal 45 dan SK Bappebti No. 6 Thn 2000)

-Dana Jaminan untuk kegiatan penyaluran amanat ke Bursa Luar Negeri (SK

BAPPEBTI No. 41 Thn 2003)
Untuk prosedur pembukaan rekening calon nasabah harus mendapatkan penjelasan mengenai investasi di perdagangan berjangka setelah itu calon nasabah atau biasa disebut investor harus mengisi formulir serta membaca ketentuan dari kontrak yang telah dibuat oleh calon nasabah dengan pialang berjangka dan apabila terdapat kesepakatan calon nasabah langsung menandatangani perjanjian dan menyetorkan dana investasinya ke bank yang sudah ditetapkan oleh badan pengawas berjangka komoditi,serta dana investasi disetor pada saat itu juga calon nasabah langsung memperoleh nomor rekening/kode nasabah. Dan sebelum melakukan transaksi calon nasabah berhak mengikuti training dari pialang berjangka sebelum melakukan transaksi di bursa berjangka.(lihat lampiran IV). Untuk prosedur penyetoran dana dilakukan hanya di bank yang sudah mendapat rekomendasi, setelah itu nasabah langsung mendapat bukti setoran dana dari perusahaaan pialang.(Lihat lampiran V). Dan untuk penarikan dana nasabah harus mengisi slip penarikan dana dan langsung menyerahkan slip penarikan dana kepada pialang berjangka untuk melakukan transaksi serta menyelurkan amanah nasabah ke bursa berjangka dan setelah diperoleh keuntungan dari hasil transaksi, maka proses pencairan 2 hari perdagangan dan langsung disetor ke rekening nasabah. .(Lihat lampiran VI).

Sedangkan untuk penutupan rekening nasabah jika tidak ada posisi di pasar maka nasabah harus membuat surat permohonan penntupan dana dan langsung mengisi slip pencairan dana, setelah itu nasabah menyerahkan perjanjian investasi disertai slip pencairannya baru akhirnya proses penutupan serta pencairan akan dilakukan 2 hari. .(Lihat lampiran VII)

Pialang berjangka harus melakukan pengecekan tentang kondisi keuangan calon nasabah sebelum ia melakukan transaksi, sesuai dengan pasal 50 undang-undang No 32 Tahun 1997 tentang perdagangan berjangka komoditi mengatur tentang ketentuan mengenai aturan dari para calon 
nasabah yang hendak membuka rekening untuk berinvestasi dalam perdagangan berjangka. Selain itu pialang berjangka tidak diijinkan menggunakan dana nasabah tanpa seizing nasabah karena ketentuannya telah diatur di pasal 52 undang-undang No 32 Tahun 1997 tentang perdagangan berjangka komoditi

Keunggulan Investasi Dalam Bursa Berjangka:

1. Modal relative terjangkau dan tidak pasif.

2. Return on Investment (ROI) tinggi (ratarata $3 \%$ per bulan)

3. Likuiditas dana tinggi, Investor dapat menarik dana sebagian atau semua maupun profit setiap saat TANPA penalty dengan prosedur yang mudah.

4. Peluang 2 arah, dapat mengambil profit pada saat harga naik atau saat harga turun.

5. Tidak dipengaruhi oleh kondisi ekonomi, politik dan keamanan dalam negeri.

6. Dukungan teknogi informasi yang canggih, cepat dan akurat lewat media Internet.

Jaminan Keamanan Investasi.

a. Transaksi perdagangan diatur oleh Undang-Undang

b. Diawasi oleh BAPPEBTI dan Lembaga Kliring Berjangka.

c. Dana investasi nasabah disimpan dalam Rekening Terpisah (Segregated Account) pada Bank BCA dan Bank Niaga yang ditunjuk oleh pemerintah.

d. Kerahasiaan dan Identitas para Investor dilindungi.

e. Dana dapat dicairkan/ditarik dalam waktu 2 hari kerja.

f. Perkembangan Investasi dilaporkan setiap hari.

g. Investor punya otoritas penuh atas setiap transaksi. (Berjangka, 2016)

Terdapat begitu banyak sengketa serta masalah hukum yang terjadi dalam perdagangan berjangka, ini mengingat perdagangan berjangka sendiri merupakan suatu hal baru yang terdapat dalam dunia investasi di Indonesia. Untuk itu kita perlu menganalisa kasus di dalam kegiatan perdagangan berjangka, dan yang akan dibahas yaitu mengenai, Permasalahan Transaksi antara Pasar Berjangka (Bursa berjangka) dengan Pasar Efek (bursa efek), serta antara nasabah dan perusahaan pialang/pialang berjangka dalam hal amanat ke bursa.

Maka dari itu perlu adanya regulasi mengenai instrument derivative karena yang jelas LQ 45 telah melanggar perdagangan dari bursa berjangka, ini menjadi sangat kompleks dimana belum adanya regulasi yang jelas mengenai instrument derivative itu sendiri, baik di bursa efek serta bursa berjangka. Hal ini menimbulkan bursa efek Surabaya dan produk LQ 45 tidak dapat disalahkan sebab aturan pun belum jelas mengaturnya padahal apabila kita tinjau dari teori ekonomi mengenai derivatif itu sudah jelas bursa efek Surabaya (LQ 45) telah hadir dalam 2 bursa yaitu bursa berjangka maupun bursa efek.

Dalam perdagangan berjangka sering kali perusahaan menggunakan dana nasabah untuk mencari keuntungannya sendiri, walaupun mungkin dana tersebut akan di kembalikan bila terjadi keuntungan tetapi dari segi hukum itu tidak dapat dibenarkan. Karena sangat jelas bahwa seagreted account atau rekening terpisah adalah murni menjadi hak dari nasabah dan digunakan untuk kepentingan nasabah dalam bertransaksi di bursa berjangka, dengan perusahaan pialang berjangka sebagai perantara maupun sarana investasi bagi investor atau nasabah.

Sesuai dengan pasal 57 undangundang No. 32 Tahun 1997 perdagangan berjangka komoditi sudah jelas bahwa setiap pihak yang telibat dilarang untuk melakukan manipulasi termasuk tindakan tidak melaporkan nasabah ke bursa. Seharusnya direksi dari perusahaan harus memperhatikan tugas dan kewajibannya berdasarkan kehati-hatian duty of skill and care demi mewujudkan kepentingan dari suatu perseroan terbatas, dalam menjalankan system manajemen perusahaan yang baik. (Wijaya, Hukum Perusahaan Perseroan Terbatas, 2013) 
Adapun sanksi yang diberikan dapat dilakukan secara pidana maupun perdata tetapi dalam hal ini Bappebti sebagai Badan pengawas seringkali menggunakan dan mengupayakan penyelesaian hukum secara mediasi terlebih dahulu. Dan melakukan pemeriksaan dan penyidikan terlebih dahulu sesuai amanah dari pasal 66 dan 67 Undang-undang tentang perdagangan berjangka komoditi. Baru kemudian setelah itu apabila terbukti Bappebti dapat melakukan pencabutan izin operasi terhadap pialang berjangka dan bersama dengan kepolisian melakukan penahanan demi mempertanggungjawabkannya di pengadilan. Untuk sanksinya terdapat sanksi administratif berupa peringatan tertulis; denda administratif, yaitu kewajiban membayar sejumlah uang tertentu; pembatasan kegiatan usaha; pembekuan kegiatan usaha; pencabutan izin usaha; pencabutan izin; pembatalan persetujuan; dan/atau pembatalan sertifikat pendaftaran dan Ketentuan pidana yang diatur dalam pasal $71 \mathrm{~s} / \mathrm{d} 76$ yang mengatur mengenai hukuman kurungan dan maksimal denda berupa uang/asset kekayaan pialang berjangka.

\section{Simpulan}

Dengan melihat dari hasil uraian telah disajikan, maka penulis memberikan beberapa kesimpulan yang diharapkan akan berguna dan bermanfaat bagi semua pihak yang memiliki minat dalam masalah yang telah dibahas dalam bab-bab yang telah disajikan. Adapun kesimpulan yang telah diambil dari pembahasan sebelumnya adalah sebagai berikut:

1. Bahwa setelah membahas mengenai Pelaku transaksi dalam investasi perdagangan berjangka di Indonesia dapat disimpulkan bahwa perdagangan berjangka ternyata memiliki aturan hukum serta mekanisme yang sangat rumit dan kompleks pula, sehingga pelaku investasi serta pihak yang terlibat dalam perdagangan berjangka pun sangat banyak, sehingga terdapat banyak lembaga yang bertanggung jawab guna menciptakan perdagangan yang kondusif, serta itu perdagangan berjangka sendiri bukan hanya melibatkan pihak dalam negeri tapi juga melibatkan pihak luar negeri sebagai mitra perdagangan dari transaksi jual beli kontrak yang terjadi dalam perdagangan berjangka sehingga regulasi maupun aturan hukumnya harus selalu mengikuti perkembangan dari mekanisme transaksi yang terjadi dalam bursa berjangka.

2. Ternyata Prosedur dan mekanisme dalam berinvestasi dan perlindungan hukum serta cara berinvestasi dalam perdagangan berjangka sangatlah rumit tetapi sudah cukup sistematis diatur oleh Undang-undang No. 32 tentang perdagangan berjangka komoditi meski begitu terdapat masalah hukum yang krusial menyangkut kewenangan pasar modal dan pasar berjangka karena pasar modal sendiri dapat ikut dalam transaksi yang sebenarnya merupakan kewenangan dari pasar berjangka, serta pada prakteknya di lapangan banyak perusahaan pialang berjangka yang masih saja melakukan pelanggaran hukum kepada nasabah tapi tindakan tegas sangat sulit diambil disebabkan sulitnya pembuktian karena mekanisme pasar yang begitu rumit dan flexibel.

\section{Referensi}

Abdulkadir Muhammad, Hukum dan Penelitian Hukum, Citra Aditya Bakti, Bandung, 2004

Bambang Sunggono, Metodologi

Penelitian Hukum, Raja Grafindo

Persada, Jakarta 2006

Guideline Jalatama Artha Berjangka, Peluang Dagang, PT Jalatama Artha Berjangka, 2006.

Hasan Zein Mahmud,"Manfaat Makro Bursa Berjangka",http://www.bbjjfx.com/default.asp.library \& link, diakses 14 oktober 2018.

Jusuf Anwar, "Hukum Ekonomi Dalam Bidang Pasar Modal", Ed. Sumantoro, UI Press, Jakarta, 2003. 
Lie Ricky Ferlianto, Evy I. Gondomulio, Tina Rosjana Laloan. Komoditi Investasi Paling Prospektif, PT Elex Media Komputindo, Jakarta, 2006,

MAJALAH FUTURES, "Perdagangan Berjangka Komoditi (Investor dan Perannya)", BAPPEBTI, Edisi September, 2006.

R. Agus Sartono, Manajemen Keuangan Internasional, BPFE-Yogyakarta, Yogyakarta, 2003
Rai Wijaya I.G., Hukum Perusahaan Perseroan Terbatas, Kesaint Blanc, Jakarta, 2003

Undang-undang No. 32 Tahun 1997 Tentang Perdagangan Berjangka Komoditi

www.bappebti.co.id, "Kewenangan Bapebti”, diakses 20 Oktober 2018. www.bbj-jfx.com, "Fungsi Utama BBJ", diakses 4 November 2018. 